\title{
Performance and Emission Features of a Light Duty Diesel Engine Generator Powered with Water-Diesel Emulsions
}

\author{
J. Sadhik Basha ${ }^{1}$ and Montaha Al Balushi ${ }^{2}$ \\ 1.2 Department of Process Engineering, International Maritime College Oman (IMCO), Sohar, \\ Sultanate of Oman.
}

\begin{tabular}{l} 
ARTICLE INFO \\
\hline Keywords: \\
Efficiency, fuel \\
consumption, IC \\
engine, pollutants, \\
surfactant
\end{tabular}

ABSTRACT

Today's world is being confronted with a couple of issues, namely environmental degradation and oil crisis. The technical community has dedicated many methods to eradicate the harmful pollutants generated from diesel engine sectors to protect the ecological environment without ensuing any inferior effect with regards to brake thermal efficiency. In this research work, normal water is incorporated with diesel fuel in the presence of surfactants (such as Span80 and Tween80) in specific proportions. The purpose of adding water with diesel fuel is to diminish the harmful pollutants and to enhance the performance features of the diesel engine. In this research investigation, totally four phases of investigation have been carried out. In the first phase, the diesel engine generator was fueled with pure diesel fuel to obtain the baseline readings (from zero load to full load). In the second phase, two fuels of water-diesel emulsions ( $2 \%$ and $4 \%$ by volume) were prepared in the presence of surfactants with the aid of a digital overhead stirrer systematically. In the third phase, stability and thermal properties of water-diesel emulsion fuels were determined. In the fourth phase, the stable water-diesel emulsion fuels were tested in a diesel engine generator and compared to those readings (performance and emission features) of pure diesel fuel. It was observed that on adding water to the diesel fuel, the performance features (such as brake thermal efficiency and brake specific fuel consumption) were improved, and harmful pollutants (such as $\mathrm{NO}_{x}, \mathrm{CO}, \mathrm{HC}$, Smoke) were diminished for the water-diesel emulsion fuels while compared to that of pure diesel fuel. 


\section{Introduction}

According to the current global environmental pollution issues that are generated from the industrial and transportation sectors, there are numerous researches have been carried out to minimize the hazardous pollutants (such as, $\mathrm{NO}_{x}$ (Nitrogen Oxides), $\mathrm{CO}$ (Carbon Monoxides), $\mathrm{CO}_{2}$ (Carbon Dioxides), and $\mathrm{HC}$ (unburnt hydrocarbons)) that are produced from the diesel engine. Due to these harmful pollutants, the environment has been affected ecologically, resulting in considerable environmental issues (for instance, ozone layer depletion, global warming, and acid rain [1-5]. To protect our environment, many scientists and environmental researchers have concocted their efforts to eradicate the global environment hitches with regards to the diesel engine power applications. The global environmental issues can be eliminated by various methodologies, such as engine design alteration techniques, exhaust gas post-treatment techniques, and fuel modification techniques. Most of the researchers [1-19] preferred fuel modification methods than the other available techniques. This is due to the fact that the fuel modification is simply workable, and does not require any engine adjustments. In modern research fuel modification techniques, many engineers and scientists devoted many efforts to improve the base fuel properties (such as diesel fuel, biodiesel fuel, petrol fuel) on adding oxygenated additives, nanoparticle additives, and normal water. Currently, the research trend has been practiced on blending normal water with diesel fuels by a process called emulsification. Emulsification is a process of mixing normal water with diesel fuel or any fuel in the presence of emulsifiers. Recent researches have revealed that on adding water with the diesel fuel, the trend of improved performance and reduced emissions can be attained. Henceforth, in this research exploration, a normal water-diesel emulsion fuel modification technique is materialized on mixing diesel fuel and normal water in the presence of emulsifiers to evaluate the performance and emission attributes of a light-duty diesel engine generator.

\section{Experimental Methodology}

The experimentation of the current research work has been carried out systematically in accordance with international standards of testing and evaluation. A light-duty diesel engine generator connected with an electrical loading was utilized for the research investigation to evaluate the performance features (brake thermal efficiency and brake specific fuel consumption) and emission features (level of $\mathrm{NO}_{x}, \mathrm{CO}, \mathrm{CO}_{2}, \mathrm{HC}$ ) from zero load to full load. The emissions from the diesel engine generator were measured by a calibrated KANE gas analyzer. During the experimentation work, starting and stopping operation of the diesel engine generator was carried out on using the pure diesel fuel. The fuel consumption of each tested fuel was measured using a burette and stopwatch combination. Using the time taken values during the fuel consumption, the performance features of the diesel engine (i.e., brake thermal efficiency and brake specific fuel consumption) were determined.

Figure 1: Experimental Setup

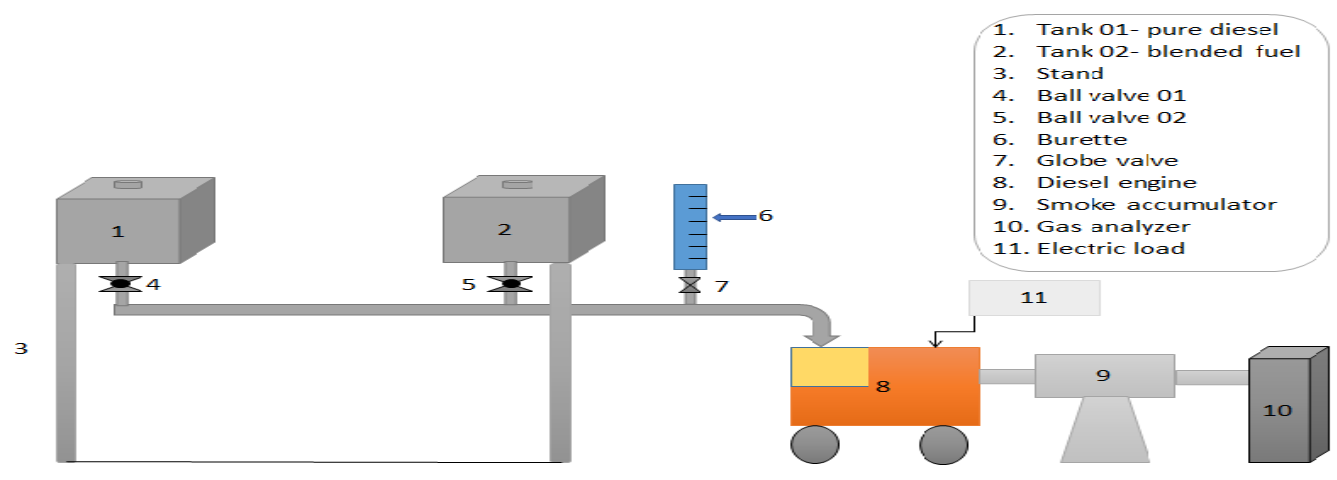


In this research investigation, totally four phases of investigation have been carried out. In the first phase, the diesel engine generator was fueled with pure diesel fuel to obtain the baseline readings. In the second phase, two fuels of water-diesel emulsions ( $2 \%$ and $4 \%$ of water by vol.) were prepared in the presence of surfactants with the aid of a digital overhead stirrer systematically. In the third phase, stability and thermal properties of water-diesel emulsion fuels were determined. In the fourth phase, the stable water-diesel emulsion fuels were tested in a diesel engine generator and compared to those readings (performance and emission features) of pure diesel fuel. With regards to performance and emission attributes of the diesel engine generator, the following characteristic curves will be studied for both diesel and additive blended diesel fuels:

1. Fuel consumption vs Engine Load

2. Emissions $\left(\mathrm{NO}_{x}, \mathrm{CO}, \mathrm{CO}_{2}, \mathrm{HC}\right)$ vs Engine Load

\section{Results and Discussions}

The features of diesel engine generator in terms of performance and emissions on using diesel and water-diesel emulsion fuels have been discussed in this section.

\subsection{Performance Attributes of the diesel engine generator}

Figure 2 and Figure 3 reveals about the brake thermal efficiency and specific fuel consumption (performance characteristics) of the diesel engine generator for all the tested fuels. It is observed from the figures that water-blended diesel fuels reflected lesser fuel consumption compared to that of neat diesel fuel. This could be due to the fact that water mixed diesel fuels consumed lesser fuel to maintain the diesel engine speed constant. Further, it could be also due to the micro-explosion and secondary atomization effects [Sadhik and Anand, 2011]. Due to secondary atomization effects, the water mixed diesel fuels could have ameliorated the degree of fuel-air mixing in the engine cylinder, and thereby enhanced the brake thermal efficiency [20]. Increased brake thermal efficiency of water mixed diesel fuels have reflected decreased brake specific fuel consumption. This is due to the fact that the brake thermal efficiency and brake specific fuel consumption are inversely proportional to each other. Figures 2 and 3 also reveals that on increasing the water content with the diesel fuel, the brake thermal efficiency feature was increased compared to that of neat diesel. At the full load $(4000 \mathrm{~W})$, the fuel consumption for the neat diesel was 0.331 $\mathrm{kg} / \mathrm{kWh}$; whereas it was $0.298 \mathrm{~kg} / \mathrm{kWh}$ and $0.289 \mathrm{~kg} / \mathrm{kWh}$ for the $98 \mathrm{D} 2 \mathrm{WS}$ and $96 \mathrm{D} 4 \mathrm{WS}$ respectively. A similar trend of enhanced brake thermal efficiency was noted for the water mixed diesel fuels compared to that of neat diesel fuel. At the full load $(4000 \mathrm{~W})$, the brake thermal efficiency for the neat diesel was $25.52 \%$; whereas it was $28.33 \%$ and $29.32 \%$ for the $98 \mathrm{D} 2 \mathrm{WS}$ and 96D4WS respectively. 
Figure 2 and Figure 3: Performance Features variation of Diesel and Water blended diesel fuels
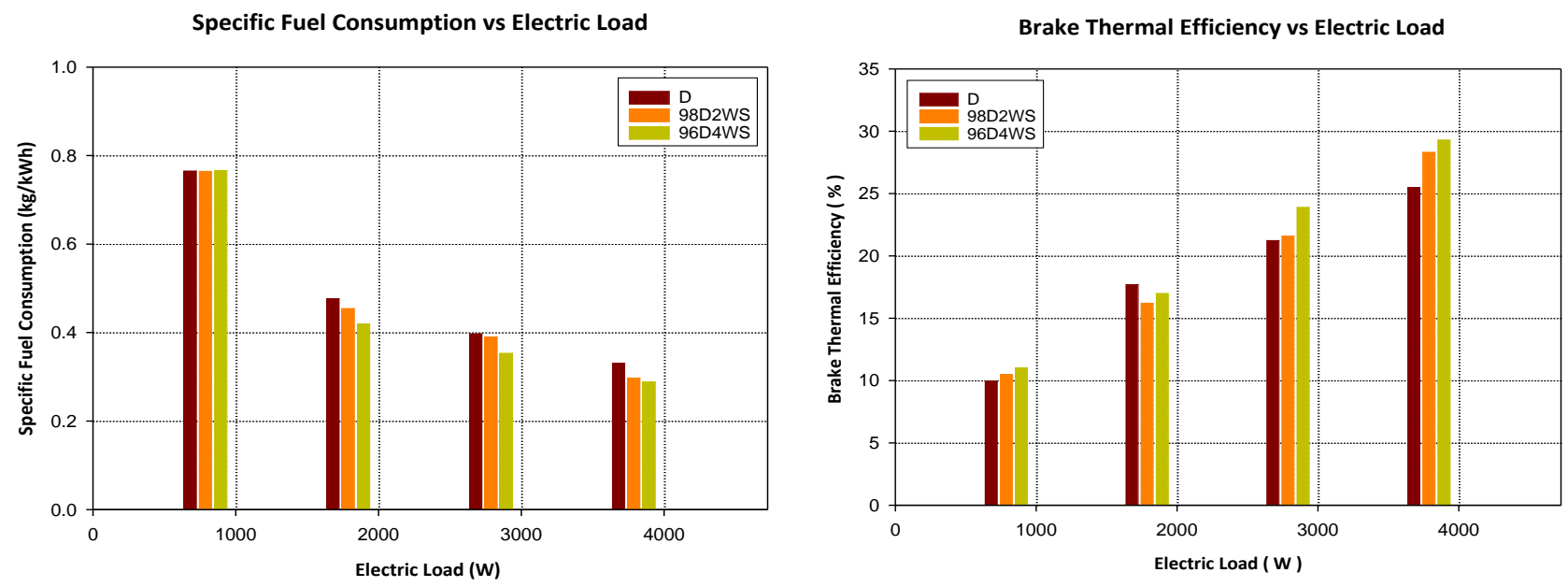

\subsection{Emission Attributes of the diesel engine generator}

The following Figures 4, 5, $6 \& 7$ indicates the emission levels of diesel fuel and water mixed diesel fuels. Improved quality of water blended diesel fuels has led to better combustion attributes in the engine cylinder. Owing to these effects, the magnitude of the emission levels $\left(\mathrm{CO}, \mathrm{CO}_{2}, \mathrm{HC}\right.$, and $\mathrm{NO}_{x}$ ) were significantly reduced for the water mixed diesel fuels while comparing to that of neat diesel fuel. The presence of water in diesel fuel has significantly influenced to reduce the harmful emissions for the water mixed diesel fuels. In accordance with the secondary atomization and micro-explosion effects associated with the water mixed diesel fuels, there could have been effects of decrement in combustion temperature and improved mixing of diesel, water droplets and air [11-19]. Owing to this fact, the combustion efficiency of the water mixed diesel fuels could have ameliorated better than that of neat diesel fuel. At the full load $(4000 \mathrm{~W})$, the $\mathrm{CO}$ emissions for the neat diesel was $0.22 \%$ (by vol.); whereas it was $0.05 \%$ and $0.04 \%$ (by vol.) for the 98D2WS and 96D4WS respectively. A similar trend of reduced $\mathrm{NO}_{x}$ emissions was noted for the water mixed diesel fuels compared to that of neat diesel fuel. At the full load $(4000 \mathrm{~W})$, the level of $\mathrm{NO}_{x}$ emissions for the neat diesel was $412 \mathrm{ppm}$; whereas it was $391 \mathrm{ppm}$ and $384 \mathrm{ppm}$ for the 98D2WS and 96D4WS respectively. A similar trend of marginal reduction of HC emissions were noted for the water mixed diesel fuels compared to that of neat diesel fuel. At the full load (4000 $\mathrm{W})$, the level of HC emissions for the neat diesel was $75 \mathrm{ppm}$; whereas it was $72 \mathrm{ppm}$ and $70 \mathrm{ppm}$ for the 98D2WS and 96D4WS respectively. 
Figure 4,5, 6 and Figure 7: Emission Features variation of Diesel and Water blended diesel fuels
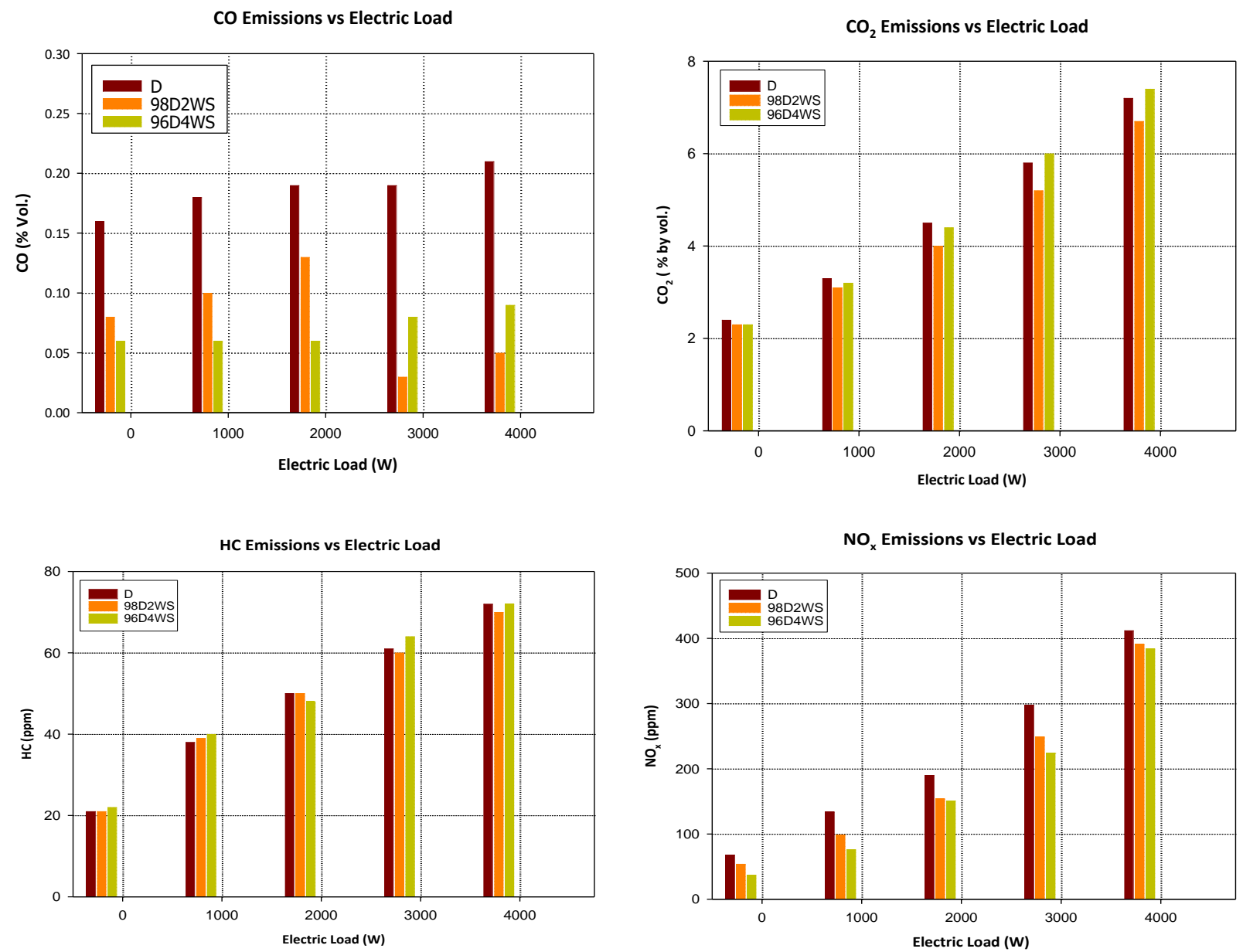

\section{Conclusions}

With a determination to enhance the performance feature and reduce emissions from a diesel engine generator, the current analysis was carried out on blending water with diesel fuel. On carrying out the experiments, the following conclusions were drawn:

- The stability of the water mixed diesel fuels (98D2WS, 96D4WS) was more than two weeks under static conditions.

- There was no abnormal noise or starting difficulty during the entire experimentation using water mixed diesel fuels.

- Water mixed diesel fuels have considerably improved the working aspects of the diesel engine generator.

- At all the loads, the monoxides of carbon and oxides of nitrogen of the water mixed diesel fuels were convincingly reduced. At the full load, the $\mathrm{CO}$ pollutants for the neat diesel was 
$0.22 \%$ (by vol.); whereas it was $0.05 \%$ and $0.04 \%$ (by vol.) for the 98D2WS and 96D4WS respectively.

Overall, it is established that $4 \%$ of water with diesel fuel has the potentiality to ameliorate the working attributes of diesel engine generator.

\section{Acknowledgment}

The research leading to these results have received funding from the Research Council (TRC) of the Sultanate of Oman under the Block Funding Program (TRC Block Funding Agreement No: FURAP/IMCO/18/008). The authors are also highly indebted to the Dean Dr. Hilal Al Hadhrami and the Management of International Maritime College Oman (IMCO) for providing us the basic facilities to carry out the above research work in a shorter period of time.

\section{Nomenclature}

$\begin{array}{lll}\mathrm{CI} & - & \text { Compression Ignition } \\ \mathrm{CO}_{2} & - & \text { Carbon Dioxides } \\ \mathrm{CO} & - & \text { Carbon Monoxides } \\ \mathrm{D} & - & \text { Diesel } \\ \mathrm{HC} & - & \text { Hydrocarbons } \\ \mathrm{NO}_{x} & - & \text { Nitrogen Oxides } \\ \mathrm{PM} & - & \text { Particulate Matter } \\ 98 \mathrm{D} 2 W S & - & 98 \% \text { of Diesel }+2 \% \text { of Water+Surfactant } \\ 96 \mathrm{D} 4 \mathrm{WS} & - & 96 \% \text { of Diesel }+4 \% \text { of Water+Surfactant }\end{array}$

\section{References}

[1] Abedin, M., Masjuki, H., Kalam, M., Sanjid, A., \& Rahman, S. (2015). Thermal Balancing of a MultiCylinder Diesel Engine Operating on Diesel, B5 and Palm Biodiesel Blends. Journal of Clean Energy Technologies, 3(2), 115-118. doi: 10.7763/jocet. 2015.v3.178.

[2] Rajkumar. (2011). Impact of Oxygen Enriched Air Intake on the Exhaust of a Single Cylinder Diesel Engine. American Journal of Environmental Sciences, 7(2), 136-140. doi: 10.3844/ajessp.2011.136.140.

[3] Song, J., Zello, V., Boehman, A., \& Waller, F. (2004). Comparison of the Impact of Intake Oxygen Enrichment and Fuel Oxygenation on Diesel Combustion and Emissions. Energy \& Fuels, 18(5), 1282-1290. doi: 10.1021/ef034103p.

[4] Basha, J., \& Anand, R. (2010). Basha, J., \& Anand, R. (2010). Performance \& emission characteristics of a DICI engine using carbon nanotubes blended diesel. Int. J. of Applied Engg. \& 
Res., 2010, 697-708.

[5] Basha, J., \& Anand, R. (2010). Performance \& emission characteristics of a DICI engine using carbon nanotubes blended diesel. Int. J. of Advances in Thermal Science \& Engg., 2010, 67-76.

[6] Basha, J., \& Anand, R. (2011). Effects of alumina nanoparticles blended jatropha biodiesel fuel on working characteristics of a diesel engine. Int. J.of Ind. Engg. \& Tech., 2011, 53-62.

[7] Basha, J., \& Anand, R. (2010). Effects of nanoparticle-blended water biodiesel emulsion fuel on working characteristics of a diesel engine. International Journal Of Global Warming, 2(4), 330. doi: 10.1504/ijgw.2010.037589.

[8] Basha, J., \& Anand, R. (2011). An Experimental Study in a CI Engine Using Nanoadditive Blended Water-Diesel Emulsion Fuel. International Journal Of Green Energy, 8(3), 332-348. doi: 10.1080/15435075.2011.557844.

[9] Sadhik Basha, J., \& Anand, R. (2011). Role of nanoadditive blended biodiesel emulsion fuel on the working characteristics of a diesel engine. Journal Of Renewable And Sustainable Energy, 3(2), 023106. doi: 10.1063/1.3575169.

[10] Basha, J., \& Anand, R. (2011). An experimental investigation in a diesel engine using carbon nanotubes blended water-diesel emulsion fuel. Proceedings Of The Institution Of Mechanical Engineers, Part A: Journal Of Power And Energy, 225(3), 279-288. doi: $10.1177 / 2041296710394247$.

[11] Basha, J., \& Anand, R. (2012). Effects of nanoparticle additive in the water-diesel emulsion fuel on the performance, emission and combustion characteristics of a diesel engine. International Journal of Vehicle Design, 59(2/3), 164. doi: 10.1504/ijvd.2012.048692.

[12] Sadhik Basha, J., \& Anand, R. (2013). The influence of nano additive blended biodiesel fuels on the working characteristics of a diesel engine. Journal Of The Brazilian Society Of Mechanical Sciences And Engineering, 35(3), 257-264. doi: 10.1007/s40430-013-0023-0

[13] Sadhik Basha, J., \& Anand, R. (2013). An experimental analysis of a diesel engine using alumina nanoparticles blended diesel fuel. SAE Technical Paper 2014-01-1391, 2014.

[14] Sadhik Basha, J., \& Anand, R. (2015). Preparation of water-biodiesel emulsion fuels with CNT \& Alumina nano-additives and their impact on the diesel engine operation. SAE Technical Paper 201501-0904, 2015.

[15] Sadhik Basha, J., \& Anand, R. (2014). Performance, emission and combustion characteristics of a diesel engine using Carbon Nanotubes blended Jatropha Methyl Ester Emulsions. Alexandria Engineering Journal, 53(2), 259-273. doi: 10.1016/j.aej.2014.04.001

[16] Sadhik Basha, J. (2018). Impact of Carbon Nanotubes and Di-Ethyl Ether as additives with biodiesel 
emulsion fuels in a diesel engine - An experimental investigation. Journal Of The Energy Institute, 91(2), 289-303. doi: 10.1016/j.joei.2016.11.006

[17] Sadhik Basha, J Applications of functionalized carbon based nanomaterials, Edited V.K. Thakur, Taylor \& Francis - CRC Press Publishers, Chapter No. 23, pp. 573-587, 2014.

[18] Sadhik Basha, J in Impact of Nano-additive blended biodiesel fuels in Diesel Engines, Edited M. Rai, Springer Publications, Chapter No. 14, pp. 325-339, 2017.

[19] Sadhik Basha, J. et al. (2019). The Influence of Hexanol and Methyl Acetate as Oxygenated Additives with Diesel Fuel in a Diesel Engine Generator. Int. Journal of IC Engines and Gas Turbines, Vol. 5, No.1, 2019.

[20] Abu-Zaid, M. (2004). Performance of single cylinder, direct injection diesel engine using water fuel emulsions. Energy Conversion and Management, 45, 697-705. 